\title{
Distribution, reproductive and energetic conditions of decapod crustaceans along the Scotia Arc (Southern Ocean)*
}

\author{
GUSTAVO A. LOVRICH ${ }^{1}$, M. CAROLINA ROMERO ${ }^{1}$, FEDERICO TAPELLA ${ }^{1}$ \\ and SVEN THATJE ${ }^{2}$ \\ ${ }^{1}$ Centro Austral de Investigaciones Científicas, CADIC-CONICET. CC 92, V9410BFD, Ushuaia, Tierra del Fuego, \\ Argentina. E-mail: lovrich@tierradelfuego.org.ar \\ ${ }^{2}$ National Oceanography Centre, School of Ocean and Earth Science, University of Southampton, European Way, \\ Southampton SO14 3ZH, United Kingdom.
}

\begin{abstract}
SUMMARY: Studies on decapod distribution patterns and reproductive and energetic conditions were carried out along the islands and shallows of the Scotia Arc (Southern Ocean) during the RV "Polarstern" LAMPOS expedition (ANT XIX/5) between April and May 2002. A clear biogeographic zonation was found. The Subantarctic Magellan-South Atlantic decapod fauna consisting of both "natant" (caridean) and "reptant" (astacidean, anomuran, and brachyuran) decapods appeared along the northern branch of the Scotia Arc to South Georgia, where Subantarctic and Antarctic faunas were found overlapping. An impoverished caridean shrimp fauna was found along the islands of the southern branch, from the South Sandwich Islands to the Antarctic Peninsula. Differences in the reproductive traits of the two most abundant species were detected. The reproductive cycle of Notocrangon antarcticus at South Georgia was more advanced than that at the South Orkney Islands, probably due to temperature differences between the two locations. Although the oogenesis and the reproductive cycle of Munida subrugosa seem to be in phase at Burdwood Bank and in the Beagle Channel, the oocyte number is probably lower at the former location. A new index was used to measure the energy devoted to reproduction by relating the energy contents of the egg mass/ovary plus hepatopancreas and the energy content of the whole body. This index revealed that the energy investment in reproduction was (1) independent of the sampling location, (2) species-specific, and (3) larger in caridean shrimps than in galatheid crabs.
\end{abstract}

Keywords: biogeography, Antarctic, Munida, Notocrangon, Campylonotus, Nematocarcinus.

RESUMEN: DISTRIBUCIÓN, CONDICIONES REPRODUCTIVAS Y ENERGÉTICAS DE CRUSTÁCEOS DECÁPODOS EN EL ARCO DE SCOTIA (OCÉANO AUSTRAL). - En abril y mayo de 2002, durante la expedición LAMPOS (ANT XIX/5) a bordo del BIO "Polarstern" se realizaron estudios sobre la distribución y condiciones reproductivas y energéticas en aguas someras del Arco de Scotia (Océano Austral). Se encontró una clara zonación biogeográfica: sobre la rama septentrional del Arco de Scotia hasta las Islas Georgias del Sur prevalece fauna de decápodos subantárticos - de la Provincia Magallanica y del Atlántico Surconstituida por "Natantia" (carideos) y "Reptantia" (astacideos, anomuros y braquiuros). En las Islas Georgias del Sur las faunas subantárticas y antárticas se superponen. En la rama meridional, desde las Islas Sandwich del Sur hasta la Península Antártica, se encontró una fauna limitada a los camarones. Se hallaron diferencias en aspectos reproductivos de dos de las especies más abundantes. El ciclo reproductivo de Notocrangon antarcticus en las Islas Georgias del Sur estaba avanzado en comparación con el de la población de las Islas Orcadas del Sur, probablemente debido a la diferencia de temperaturas entre ambas localidades. A pesar que la oogenesis y el ciclo reproductivo de Munida subrugosa parecieran estar en fase en el Banco Burdwood y en el Canal Beagle, el número de oocitos es probablemente menor en la primera localidad. Se utilizó un nuevo índice que relaciona el contenido energético entre la masa de huevos/ovario más el hepatopancreas y el contenido energético del animal completo. Este índice reveló que la inversión energética en reproducción fue (1) independiente de la localidad, (2) especie-específica y (3) más alta en camarones que en cangrejos galateidos.

Palabras clave: biogeografía, Antártida, Munida, Notocrangon, Campylonotus, Nematocarcinus. 


\section{INTRODUCTION}

Southern Ocean benthic decapods are among the best marine biological examples for a clear zoogeographic separation of the Antarctic from the Subantarctic or antiboreal provinces, such as the Magellan region of South America (Hedgpeth, 1969; Gorny, 1999). This is demonstrated by a rich Subantarctic decapod fauna including various "reptant" (Astacidea, Anomura, and Brachyura) and "natant" (Caridea) families, in comparison with a strongly impoverished caridean shrimp fauna and a few lithodid crabs left in Antarctic waters south of the Polar Frontal system (Gorny, 1999; Thatje and Arntz, 2004). The reasons for this impoverishment in decapod diversity towards polar seas in general are numerous, but have been principally attributed to physiological constraints and a lack of life history adaptations to polar conditions (for discussion see Frederich et al., 2001; Thatje et al., 2003; 2005).

The Magellan region is the geographically closest Subantarctic Province to Antarctica (Hedpgeth, 1969). Both regions probably remain geographically connected by the islands and shallow waters of the Scotia Arc (Fig. 1). From a biogeographic point of view, this submarine extension of the South American Andes may constitute a transitional biogeographic area for decapods from either side - the
Antarctic and the cold-temperate waters (Arntz et al., 1999). Hence, the Scotia Arc can be considered as a key zone for the study of changes in decapod life history and distribution, indicating both evolutionary pathways and changes in the marine biota through geological times (Crame, 1999; Thatje et al., 2005).

The reproductive effort (RE) is a suitable parameter for elucidating energy investment in reproduction (Clarke, 1987) but is rarely used in decapods (Fernández et al., 2000; Brante et al., 2003). So far, the RE has been a difficult parameter to measure, because it involves a great deal of detailed physiological work. In fact, this parameter considers the cost of activity associated with reproduction, the associated respiratory cost, gonad production and the energy assimilated (Clarke, 1987). The reproductive output (RO) has been commonly used as a proxy parameter for RE, especially in marine invertebrates (Hughes and Roberts, 1980; Hines, 1982; Havenhand and Todd, 1989). The RO is calculated as the ratio between gonad and body masses (Clarke, 1987), and particularly in decapods as the ratio between egg and body masses (Hines, 1982). The RO is an inadequate estimator of RE in the case of brooding species, because the energy allocated to brood care is not considered (Fernández et al., 2000; Brante et al., 2003). However, given the

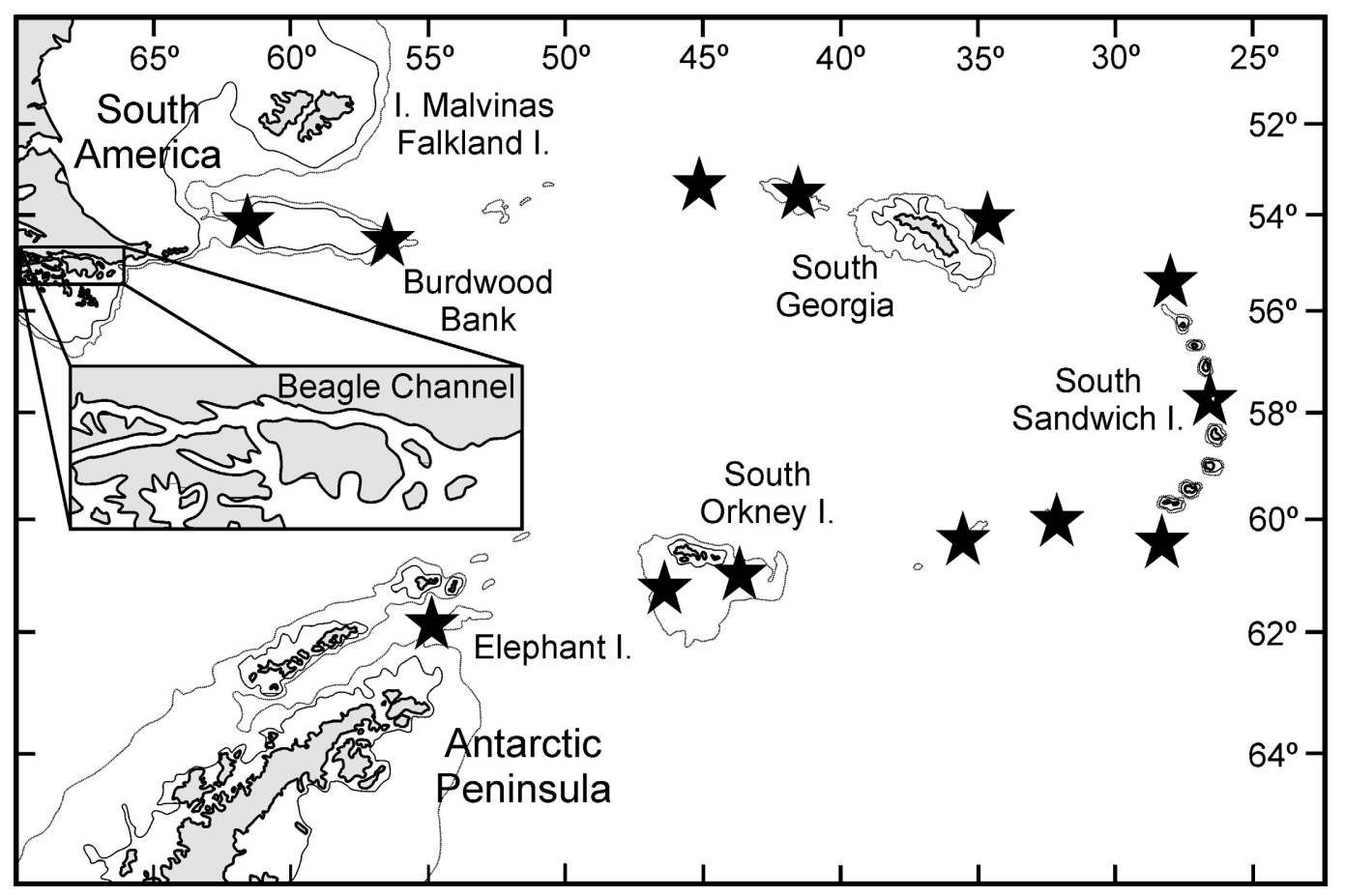

FIG. 1. - Area under investigation, with indication of sampling stations (stars), from the Subantarctic Magellan region of South America along the Scotia Arc islands to the Antarctic Peninsula. 
logistic limitations to accessing good quality samples from polar seas, the RO may still be considered as an approximation which allows comparisons of energy investment in reproduction in related species at the same phase of their reproductive cycle.

Energetic costs of reproduction in high latitudinal decapods have been widely restricted to comparisons of lipid and fatty acid contents of eggs in relation to fecundity and female size (Clarke, 1979, 1983 ) as a measure of ecological fitness (Graeve and Wehrtmann, 2003; Thatje et al., 2004). Whereas early studies suggested clines in energy contents of eggs as an indicator for latitudinal changes in environmental conditions, mainly temperature and food availability (e.g. Wehrtmann and Kattner, 1998), a recent study indicated no substantial difference in polar shrimp eggs compared to those of related taxa from temperate and tropical regions (Graeve and Wehrtmann, 2003).

Even if the decapod composition at either side of the Antarctic Convergence is different, we expect energy content to change in response to varying environmental conditions. In this context, energetic and reproductive parameters are supposed to reflect the ecological fitness of species living at their distributional limits. In this paper, we describe the reproductive status, the reproductive output and the energy content of the most abundant decapods along the Scotia Arc. We introduce a new index, including the hepatopancreatic energy, which measures the energy devoted to egg production, and thus allows a comparison between populations or species desynchronised in their reproductive cycle.

\section{MATERIALS AND METHODS}

\section{Sampling of decapod material}

Decapods were collected during the XIX/5 (LAMPOS) expedition of RV "Polarstern" along the Scotia Arc between 3 April and 5 May 2002 (Fig. 1). Samples were collected with an Agassiz trawl (AGT) and a fish bottom trawl. Detailed cruise information has been published by Arntz and Brey (2003).

In order to compare reproductive and energetic conditions along latitude/longitude, additional material of three decapod species was sampled in the Beagle Channel (Fig. 1). In March, May and July 2002, and May 2003, samples of Munida subrugosa, Campylonotus vagans and C. semistriatus were obtained. Sampling was done using an epibenthic trawl operated with an inflatable dinghy (see Tapella et al., 2002 for details).

In each sampling, all decapods were separated from the catch, placed on ice and identified to species level according to Boschi et al. (1992) and Retamal (2000). Animals were sorted by sex, counted, and their carapace length (CL) was measured with a digital caliper to the nearest $0.01 \mathrm{~mm}$. Sex was differentiated from differences in pleopod morphology or presence of eggs. The proportion of ovigerous females was evaluated from the presence of eggs attached to the pleopods. At least 20 females of frequently occurring species from each haul were randomly selected and dissected. Gonads were sorted into different developmental stages according to their general appearance (colour, gonad and oocyte sizes, c.f. Tapella et al., 2002). Gonads, hepatopancreas and eggs were removed, dried separately to constant weight at $55^{\circ} \mathrm{C}$ and pelletised. The caloric content of each sample was obtained by burning pellets of 20-200 mg in an adiabatic calorimeter (Parr model 1425). Energy values were calculated using standard equations (Parr Instrument Company, 1993). The values obtained were corrected for ash and acid content and expressed as $\mathrm{kJ} \cdot \mathrm{g}^{-1}$ ash free dry mass (AFDM). Differences in the energy content of ovaries or egg mass and hepatopancreas were analysed using one-way analysis of variance (ANOVA, Sokal and Rohlf, 1995).

The reproductive status was studied using several parameters. Oocyte diameter was measured using a binocular microscope and a gridded eyepiece with a precision of $\pm 0.17 \mathrm{~mm}$. The gonado-somatic index was estimated as the ratio between ovary and whole body dry mass. The reproductive output (RO) was calculated as the ratio between the egg mass and body dry mass. The energy condition associated with reproduction (reproductive investment) was estimated using two different indices. Indices were calculated as ratios between the energy contents (EC) of (a) ovary or egg clutch and the whole female $\left(\mathrm{EI}_{\mathrm{a}}\right.$ ), as compared to the RO, or (b) ovary or egg clutch plus the hepatopancreas and the whole female $\left(\mathrm{EI}_{\mathrm{b}}\right)$. In all cases, the body mass or energy in the denominator of the calculations included all the body parts, e.g. the ovary. We decided to incorporate the energy content of the hepatopancreas in $\mathrm{EI}_{\mathrm{b}}$ because this organ stores energy in the form of lipids just before or during the ovarian development and is the main energy supply to the ovary during the secondary vitellogenesis (Chapelle, 1977; Mourente 
TABLE 1. - Species list of benthic decapod crustaceans collected along the Scotia Arc during the cruise ANT XIX/5 (LAMPOS) in April/May 2002. Numbers represent the total specimens caught per species. References: Shag-Georgia refers to Shag Rocks and South Georgia; Banks refers to Herdman and Discovery Banks.

\begin{tabular}{|c|c|c|c|c|c|c|c|c|}
\hline \multirow{2}{*}{ Infraorder } & \multirow{2}{*}{ Family } & \multirow{2}{*}{ Species } & \multicolumn{6}{|c|}{ Localities } \\
\hline & & & $\begin{array}{l}\text { Burdwood } \\
\text { Bank }\end{array}$ & $\begin{array}{l}\text { Shag- } \\
\text { Georgia }\end{array}$ & $\begin{array}{l}\text { South Sandwich } \\
\text { Islands }\end{array}$ & Banks & $\begin{array}{l}\text { South Orkney } \\
\text { Islands }\end{array}$ & $\begin{array}{l}\text { Elephant } \\
\text { Island }\end{array}$ \\
\hline \multirow[t]{8}{*}{ Caridea } & & Undetermined Caridea & 1 & & 1 & & & \\
\hline & Nematocarcinidae & Nematocarcinus lanceopes & & & 10 & & & \\
\hline & Hippolytidae & Chorismus antarcticus & & 2 & & & & \\
\hline & & Undetermined sp. 1 & & & 3 & & & \\
\hline & Crangonidae & Notocrangon antarcticus & & 401 & & & 253 & 3 \\
\hline & Campylonotidae & Campylonotus semistriatus & & 10 & & & & \\
\hline & & Campylonotus vagans & 1 & & & & & \\
\hline & Palaemonidae & $\begin{array}{l}\text { Undetermined sp. } 2 \\
\text { Undetermined sp. } 3\end{array}$ & 1 & & 2 & 1 & & \\
\hline & Nephropsidae & & 2 & & 2 & 1 & & \\
\hline \multirow{6}{*}{ Anomura } & Galatheidae & Munida subrugosa & 238 & & & & & \\
\hline & & Munida spinosa & 10 & & & & & \\
\hline & Paguridae & Pagurus comptus & 3 & & & & & \\
\hline & & Pagurus forceps & 3 & & & & & \\
\hline & Lithodidae & Paralomis spinosissima & & 4 & & & & \\
\hline & & Lithodes confundens & 3 & 3 & & & & \\
\hline \multirow[t]{3}{*}{ Brachyura } & Majidae & Eurypodius latreillei & 27 & & & & & \\
\hline & & Eurypodius longirostris & 6 & & & & & \\
\hline & & Eurypodius sp. & 1 & & & & & \\
\hline \multicolumn{3}{|c|}{ Species number } & 12 & 5 & 5 & 1 & 1 & 1 \\
\hline
\end{tabular}

and Rodríguez, 1991; Haefner and Spaargaren, 1993). This approach is particularly useful for comparing species in different reproductive states imposed by variable environments, climate zones or latitude. Hence, the $\mathrm{EI}_{\mathrm{b}}$ index would better show changes in the reproductive effort of species in different reproductive statuses.

Differences in the $\mathrm{EI}_{\mathrm{b}}$ index, EC of ovary or egg mass, and EC of hepatopancreas among crustaceans were analysed using one-way analysis of variance (ANOVA). The assumptions of normality and homogeneity of variances were tested in all cases with the Kolmogorov-Smirnov and Bartlett tests respectively (Sokal and Rohlf, 1995). Unplanned comparisons were done when significant differences were found. Null hypotheses of equality of reproductive parameters between Anomura and Caridea were tested with a one-way ANOVA and orthogonal contrasts.

\section{RESULTS}

\section{Species composition and distribution of benthic Decapoda along the Scotia Arc}

Sampling stations close to the South American continent showed the highest species richness when compared with the stations sampled along the Scotia
Arc (Table 1). At Burdwood Bank, a predominance of the galatheid crab Munida subrugosa, an abundant species of the channels and fjords of Tierra del Fuego, was found. The most abundant species following $M$. subrugosa were majid species of the genus Eurypodius, the only brachyuran crab in our samples. The first faunistic change in Magellan Province fauna was observed at Shag Rocks, close to South Georgia, where lithodid crabs were still present, but represented by different species than in the Magellan region and at Burdwood Bank (Table 1). However, the caridean shrimp Campylonotus semistriatus, typical of Magellan and south-west Atlantic waters, still constituted a faunistic element of Shag Rock waters. South of South Georgia, the decapod fauna was only represented by Antarctic shrimp species, being dominated by Notocrangon antarcticus (Table 1). Further south, the shallow waters off the Sandwich Islands revealed an extremely poor decapod fauna. Off South Orkney and Elephant Islands, $N$. antarcticus was the only representative of decapod shrimps, where decapodid and juvenile stages (3 individuals of 2.0, 2.3 and 3.3 $\mathrm{mm} \mathrm{CL}$ ) were also caught for the first time.

\section{Reproductive condition}

All female Munida subrugosa captured at Burdwood Bank were non-ovigerous (Table 2) and 


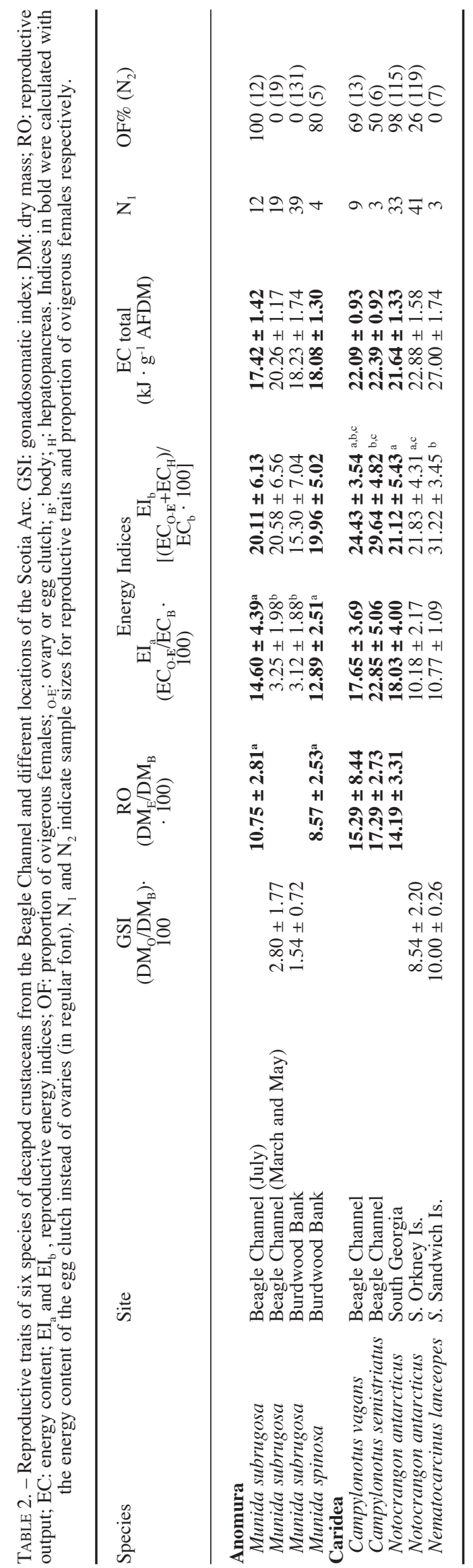

showed a wide size range (Fig. 2). Particularly small specimens $(<8 \mathrm{~mm} \mathrm{CL})$ occurred at this site, a pattern similar to populations at greater depths of the Beagle Channel, > 90 m depth (c.f Tapella, 2002). In the Beagle Channel females and males attain physiological maturity at 9.9 and $8.0 \mathrm{~mm}$ CL respectively (Tapella et al., 2002). Accordingly, at Burdwood Bank 5.6 and $18.6 \%$ of females and males respectively were immature. In April, gonads of M. subrugosa from the Burdwood Bank were less developed than those in the Beagle Channel. In the former location, the gonado-somatic index was significantly lower than in the Beagle Channel (Table 2), but the oocyte diameter was identical (Burdwood Bank: $0.22 \pm 0.01 \mathrm{~mm}$; Beagle Channel: $0.22 \pm 0.02 \mathrm{~mm}$ ). In M. spinosa from Burdwood Bank the majority of females were carrying undifferentiated eggs in April (Table 2), whereas in M. subrugosa in the Beagle Channel egg extrusion occurs in July (Tapella et al., 2002). However, both species of Munida showed comparable reproductive outputs at the two different locations: the RO, and $\mathrm{EI}_{\mathrm{a}}$ of $M$. subrugosa from the Beagle Channel recorded in July were similar to those of M. spinosa from the Burdwood Bank in April (Table 2).

Clear differences in the reproductive condition were detected in the two geographically separated populations of Notocrangon antarcticus. At South Georgia, $98 \%$ of female $N$. antarcticus were ovigerous (Table 2; Fig. 2), carrying undifferentiated eggs with non-developed ovaries (Fig. 3). In contrast, off the South Orkney Islands only $26 \%$ of all captured females were egg-carrying (Table 2; Fig. 2), though non-ovigerous individuals showed relatively welldeveloped gonads (Fig. 3; Table 2). Hence, these females were assumed to be close to egg-extrusion. Differences between the GSI at the South Orkney Islands and the RO at South Georgia, along with differences in $\mathrm{EI}_{\mathrm{a}}$ at both locations, indicate that the reproductive cycle in $N$. antarcticus is delayed at the South Orkney Islands (Table 2). The smallest ovigerous females occurring in our samples were 11.9 and $15.4 \mathrm{~mm} \mathrm{CL}$ at South Georgia and the South Orkney Islands respectively (Fig. 2), indicating differences in size at gonadal maturity in both populations. Size frequency distributions also differed between locations (Fig. 2). On average, female $N$. antarcticus at South Georgia were smaller (14.6 $\pm 1.2 \mathrm{~mm} \mathrm{CL}$ ) than those from the South Orkney Islands $(16.6 \pm 1.3 \mathrm{~mm} \mathrm{CL})$. Size frequency distributions of males were more dispersed (Fig. 2) and their mean sizes were $12.2 \pm 3.3$ and $13.3 \pm 2.6 \mathrm{~mm}$ 


\section{Females}
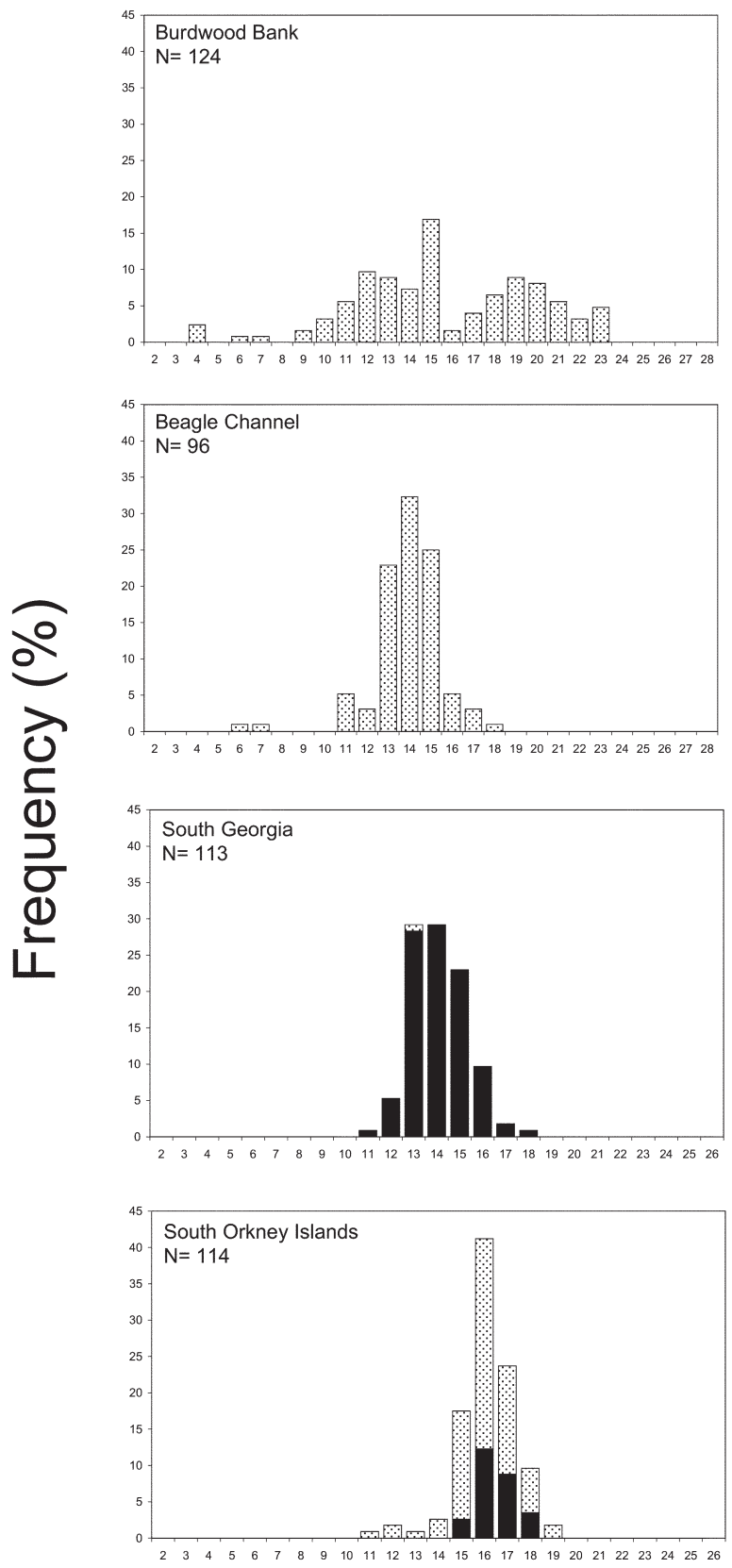

Males
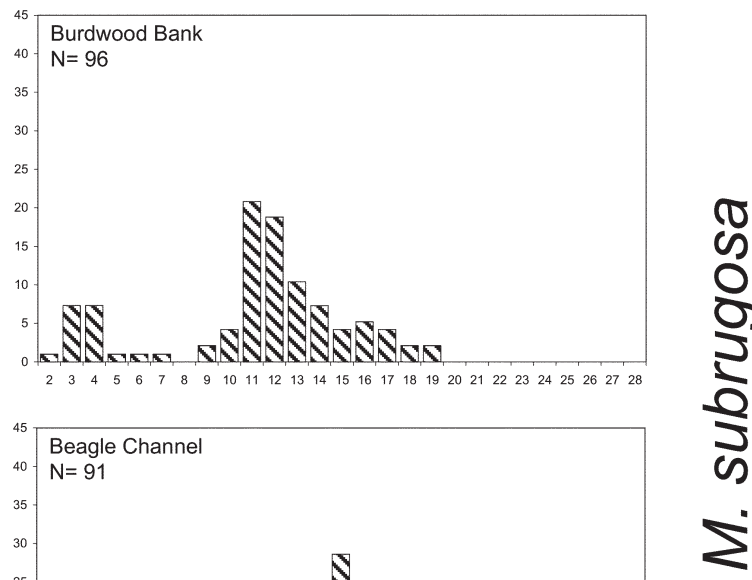

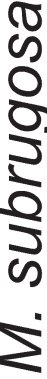
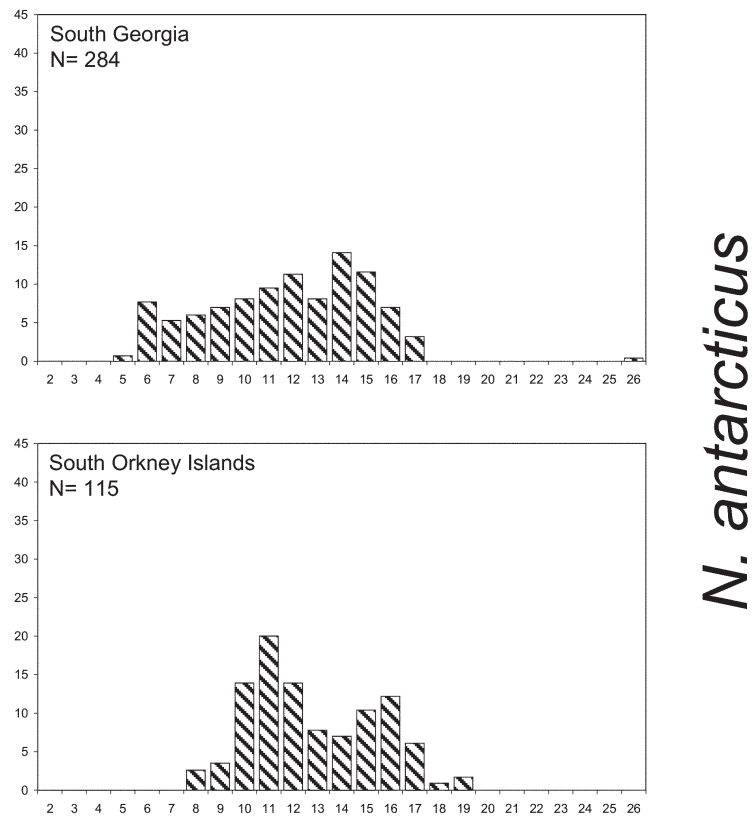

NANANANANN

$(\mathrm{mm} \mathrm{CL})$

FIG. 2. - Size frequency distributions for male and female Munida subrugosa from the Burdwood Bank and the Beagle Channel, and Notocrangon antarcticus from South Georgia and the South Orkney Islands. Ovigerous females are represented by black bars. N = sample size.

CL at South Georgia and the South Orkney Islands respectively.

The RO was different in the two decapod groups (Table 2). Principally, anomurans showed significantly lower values of RO than carideans $\left(\mathrm{F}_{\text {ANOvA }}\right.$ $\left.=4.1 ; \mathrm{p}=0.005 ; \mathrm{F}_{\text {contrasts }}=14.1 ; \mathrm{p}<0.001\right)$. Among caridean shrimps, RO variability was relatively high, even within the same genus, as for example in Campylonotus (Table 2). When the reproductive investment is expressed as the energy content of the ovary in relation to that of the body $\left(\mathrm{EI}_{\mathrm{a}}\right)$, differences became less evident (Table 2, bold numbers). The highest, although statistically non-significant, values of $\mathrm{EI}_{\mathrm{a}}$ were those of species from the Beagle 


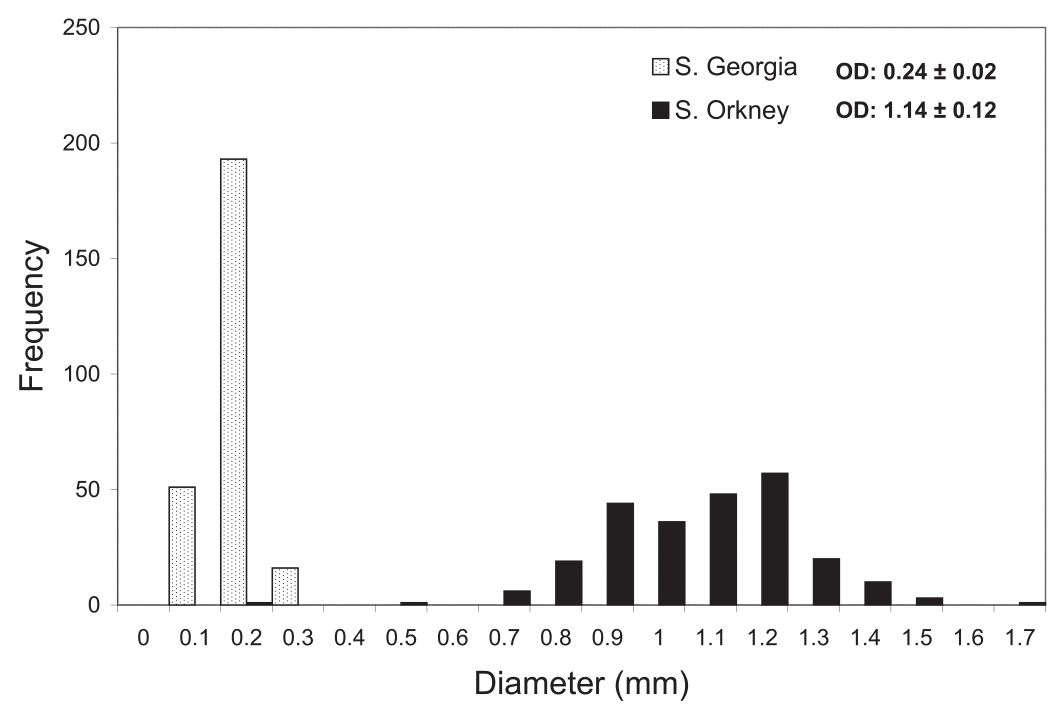

FIG. 3. - Size frequency distribution of oocyte diameter in Notocrangon antarcticus in waters off South Georgia (grey bars) and the South Orkney Islands (black bars). Average oocyte diameter (OD) and one standard deviation are indicated at the top right.

Channel, namely M. subrugosa and C. semistriatus. Among the species with ovigerous females, the lowest $\mathrm{EI}_{\mathrm{a}}$ was shown by M. spinosa at Burdwood Bank (Table 2).

In those species of which two populations were sampled, comparisons between GSI and RO, and between $\mathrm{EI}_{\mathrm{a}}$, indicated geographic differences in the oogenesis process. In M. subrugosa the GSI at Burdwood Bank in April corresponded to $14 \%$ of the $\mathrm{RO}$ in the Beagle Channel in July just after egg extrusion. Likewise, $\mathrm{EI}_{\mathrm{a}}$ at both locations at Burdwood Bank (in April) and in the Beagle Channel (in March and May) reached about $20 \%$ of the maximum value found in the Beagle Channel in July. Hence, in April 2002, the secondary vitellogenesis of $M$. subrugosa, i.e. lipid accumulation in the ovary, was starting in both locations. In N. antarcticus off the South Orkney Islands, the $\mathrm{EI}_{\mathrm{a}}$ represented $56 \%$ of values found at South Georgia, where eggs were recently extruded. This suggests that in the South Orkney Island population the secondary vitellogenesis was advanced and the oocytes were close to extrusion (c.f. Fig. 3).

\section{Energy condition}

Table 2 summarises the total energy content by species and sampling site. EC was higher in caridean than in anomuran species $\left(\mathrm{F}_{\mathrm{ANOVA}}=47.6\right.$; $\left.\mathrm{p}<0.001 ; \mathrm{F}_{\text {contrasts }}=207.1 ; \mathrm{p}<0.001\right)$. Among Munida spp. the total and ovarian energy contents (ECs) were similar among the different sampling locations (Table 2; Fig. 4). The only observed difference in energy conditions of $M$. subrugosa was a lower hepatopancreatic EC at Burdwood Bank than in the Beagle Channel (Tukey test $\mathrm{p}<0.001$; Fig. 4). Among carideans, total EC differed significantly (Table 2; Fig. 4). Differences were due to the high EC of $N$. lanceopes, reflected by a significantly high EC of ovaries and hepatopancreas. In N. antarcticus, the hepatopancreatic EC was significantly lower at South Georgia than at the South Orkney Islands (Tukey test $\mathrm{p}<0.001$; Fig. 3).

A typical reproductive energy index that involves the energy contents of egg or ovaries and the somatic energy $\left(E_{\mathrm{a}}\right)$ was useless for comparison between species at different stages of their reproductive cycle, because delays in the ovarian development due to geographic differential distribution were not reflected (Table 2). For example, M. subrugosa with developing ovaries sampled during the secondary oogenesis (March-May) showed lower EI than individuals with already extruded eggs (July). Likewise, in Notocrangon antarcticus from South Georgia with recently extruded eggs, the $\mathrm{EI}_{\mathrm{a}}$ was higher than in those off the South Orkney Islands, where oocytes were in the final phase of development. Conversely, when the hepatopancreas was included in the index, $\mathrm{EI}_{\mathrm{b}}$ values were more comparable in measuring the reproductive output among the species in a different reproductive status (Table 2). The $\mathrm{EI}_{\mathrm{b}}$ was similar among Anomura, i.e. Munida spp. $(\mathrm{F}=1.81 ; \mathrm{p}=0.17)$, and different among caridean species $(\mathrm{F}=5.56$; $\mathrm{p}<0.001)$. This difference was due to $N$. lanceopes from the South Sandwich Islands, which showed a significantly higher $\mathrm{EI}_{\mathrm{b}}$ than $N$. antarcticus from the 


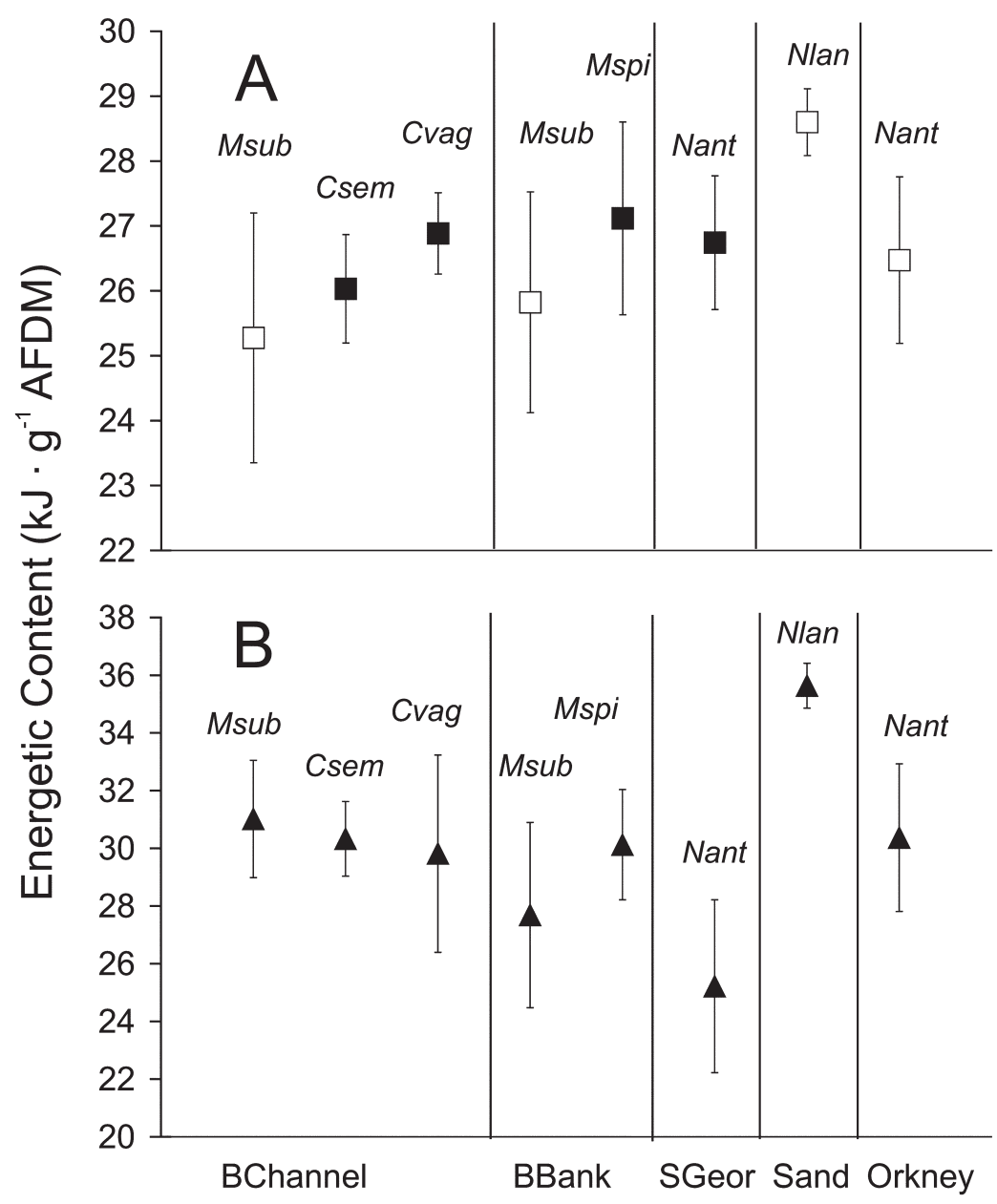

FIG. 4. - Average energy content $\left(\mathrm{kJ} \cdot \mathrm{g}^{-1} \mathrm{AFDM}\right) \pm 1$ standard deviation of (A) ovary or egg mass (full and empty squares respectively), and (B) hepatopancreas from decapod species in the Beagle Channel and along the Scotia Arc. References: Msub: Munida subrugosa; Mspi: M. spinosa; Csem: Campylonutus semistriatus; Cvag: C. vagans; Nant: Notocrangon antarcticus; Nlan: Nematocarcinus lanceopes; BChannel: Beagle Channel; BBank: Burdwood Bank; SGeor: South Georgia; Sand: South Sandwich Islands; Orkney: South Orkney Islands.

South Orkney Islands and South Georgia (Table 2). The two populations of $N$. antarcticus showed a similar $\mathrm{EI}_{\mathrm{b}}$.

\section{DISCUSSION}

\section{Decapod biogeography along the Scotia Arc}

We found an extension of the Magellan fauna towards South Georgia along the shallows of the northern branch of the Scotia Arc. At least for the decapod fauna, South Georgia has been formerly considered to be part of the Antarctic biogeographic region (Gorny, 1999). However, the coexistence of typically Subantarctic lithodids (see Thatje and Arntz, 2004 for a review) and shrimps such as Campylonotus semistriatus with Antarctic shrimps Chorismus antarcticus and Notocrangon antarcticus probably justifies considering this area as transitional for decapod distribution. Currents associated with the dominant West Wind Drift, e.g. the Cape Horn and Malvinas-Falklands currents, may disperse planktonic larvae of species occurring off the southern tip of South America (Antezana, 1999). Planktonic larvae of most benthic decapods occurring in southern South America-even those typically intertidal species such as Halicarcinus planatuswere also found at Burdwood Bank (Bacardit, 1986). However, given the distributional depth limits of both Anomura and Brachyura (Gorny, 1999), their presence along the northern branch of the Scotia Arc is probably only possible in the scattered shallows, which serve as biogeographic stepping stones and local refuges. However, few data are available for the deep waters of the Scotia Arc and future research should explore their role in faunal exchange. In particular the deep-sea trenches east 
off the Scotia Arc could be pathways of interchange for some benthic decapod species (Thatje and Arntz, 2004) if physiological constraints imposed by low water temperatures could be overcome (Thatje et al., 2005).

\section{Reproductive conditions}

The scarcity of decapods sampled from different populations does not allow for generalisations about decapod reproductive patterns along the Scotia Arc. Nevertheless, we detected differences in the reproductive cycle of the two most abundant species. The oogenesis and therefore the reproductive cycle of Munida subrugosa from the Burdwood Bank seems to be in phase with that of those from the Beagle Channel, since the oocyte diameter and the relative energy of the ovary were similar. However, the GSI and the energy content of the hepatopancreas in $M$. subrugosa from the Burdwood Bank were lower, contrasting with the similar $\mathrm{RO}, \mathrm{EI}_{\mathrm{b}}$ and hepatopancreas energy content of $M$. subrugosa from the Beagle Channel and M. spinosa from the Burdwood Bank. Munida subrugosa inhabits the cold temperate waters off the southern tip of South America (Matthews, 1932; Retamal, 1981; Boschi et al., 1992). This study extends the geographical distribution of $M$. subrugosa southeast to the Burdwood Bank (c.f. Rayner, 1935; Boschi et al., 1992), and this site probably constitutes a marginal habitat for this species. During the secondary oogenesis, the ovarian quality, i.e. mass and energy contents, of $M$. subrugosa is determined by the food type (Romero, 2003). Hence, food availability and poor environmental conditions, reflected by a low hepatopancreatic energy content, probably constrain ovarian development, resulting in a low GSI. This indicates that oocytes will probably be less numerous though they contain the same energy content as in areas in which M. subrugosa is a dominant faunistic element, like the Beagle Channel (Gutt et al., 1999; Pérez-Barros et al., 2004).

The most important difference in the reproductive cycle and associated energy parameters was found in Notocrangon antarcticus. The reproductive cycle at South Georgia was advanced in comparison with that at the South Orkney Islands. This is probably due to higher temperatures north of the Antarctic Convergence. Bottom temperature was 2.2 and $-0.15^{\circ} \mathrm{C}$ off South Georgia and the South Orkney Islands respectively (Grabbert et al., 2003). In ectotherm invertebrates, temperature is the main exogenous factor which determines the extent of oogenesis and growth (e.g. Bergstrom, 1991; Pearse and Mc Clintock, 1991; Calcagno et al., 2005) and is likely to be responsible for the differences in ovarian development rate and female maturity size between South Georgia and the South Orkney Islands. Differences in reproductive timing of $N$. antarcticus between the same locations were also reported by Makarov (1970). Females attain size at maturity earlier and fecundity is higher in waters off South Georgia than at the South Orkney Islands (Makarov, 1970).

Lipid mobilization between the hepatopancreas and ovaries, and eventually to the eggs, justifies the inclusion of the hepatopancreas energy in the $\left(\mathrm{EI}_{\mathrm{b}}\right)$ index. During the oocyte lipid deposition, i. e. secondary vitellogenesis, events that involve the energy flux can be summarised as follows. Prior to ovarian growth, lipids accumulate in the hepatopancreas during a variable period of time. Then, lipids are transported to and deposited in the oocytes, with the increase in energy in the ovary and the concurrent decrease in the hepatopancreatic energy. During and shortly after egg intrusion, both the ovary and the hepatopancreas have low energy contents, and finally the hepatopancreas recovers by re-building its energy reserves (Harrison, 1990; Mourente and Rodríguez, 1991; Haefner and Spaargaren, 1993; Styrishave and Andersen, 2000; Albessard et al., 2001; Wen et al., 2001).

The inclusion of the hepatopancreatic energy into an index $\left(\mathrm{EI}_{\mathrm{b}}\right)$ allowed us to make comparisons between species with differences in the timing of their reproductive cycle. Oocyte extrusion of Notocrangon antarcticus in the South Orkney Islands was later than at South Georgia, where females were mostly ovigerous, with a very recently spent ovary and had a hepatopancreas with a lower energy content than those from the South Orkney Islands (Fig. 4B). The difference between the maximum ovary size and a developing ovary is the difference between the RO at South Georgia and the GSI at the South Orkney Islands. We interpret that the higher energy value in the hepatopancreas of $N$. antarcticus at the South Orkney Islands occurs because this energy is still to be transferred to ovary growth. The index $\left(\mathrm{EI}_{\mathrm{b}}\right)$ revealed that the energy allocated to egg production plus that stored in the hepatopancreas is similar at the two locations. Nematocarcinus lanceopes exhibited ripe gonads and the GSI represented $63 \%$ of the maximum GSI reported by Gorny and George (1997), which is 
comparable to $60 \%$ of the GSI:RO ratio for $N$. antarcticus at the two sample sites. Hence, we assume that during April 2002 N. lanceopes were in the final phase of the secondary vitellogenesis, suggesting that egg extrusion would occur at the same time as in $N$. antarcticus off the South Orkneys. Therefore, the $\mathrm{EI}_{\mathrm{b}}$ is comparable among all Caridea sampled for this study.

Our results show that this new index $\mathrm{EI}_{\mathrm{b}}$ is species-specific and independent of the sampling location and reproductive status. The $\mathrm{EI}_{\mathrm{b}}$ does not reflect a clear trend along the Scotia Arc. For example, in Notocrangon antarcticus from different localities, $\mathrm{EI}_{\mathrm{b}}$ values and thus the reproductive investment are the same, regardless of whether females are in the secondary oogenesis or carrying eggs. Our results of higher $\mathrm{EI}_{\mathrm{b}}$ in $N$. lanceopes than in $N$. antarcticus are consistent with the higher egg lipid content in the former species (Graeve and Wehrtmann, 2003), and justify the inclusion of hepatopancreatic energy into the index. The Subantarctic shrimp $C$. semistriatus shows higher $\mathrm{EI}_{\mathrm{b}}$ than $N$. antarcticus, both near the Antarctic Convergence (South Georgia) and in the Antarctic waters off the South Orkneys. Although the $\mathrm{EI}_{\mathrm{b}}$ index does not consider the cost of egg-care (c.f. Brante et al., 2003), this approximation allowed us to obtain a reliable estimation of investment in egg production, and is useful for comparing species with a different reproductive status obtained from a single sampling period, or for making latitudinal comparison without a time series. If this period coincides with-or is close to-egg extrusion, this index could be useful for comparing the energy investment in egg production between related species or different populations of a single species.

\section{ACKNOWLEDGEMENTS}

Our thanks are due to the Dirección de Aeronáutica of the Province of Tierra del Fuego for transportation from Ushuaia (Tierra del Fuego, Argentina) to Punta Arenas (Chile) and back home, and to the master and crew of RV "Polarstern" for their professional support at sea. We would like to thank M. Gutiérrez, C. De Roccis and V. Mattenet for their field and laboratory assistance. This study was partially funded by the Fundación Antorchas (Argentina) and CONICET (PIP 02944). The authors would like to thank Wolf Arntz, Klaus Anger and Ingo Wehrtmann for constructive comments on an earlier draft.

\section{REFERENCES}

Albessard, E., P. Mayzaud and J. Cuzin-Roudy. 2001. - Variation of lipid classes among organs of the northern krill Meganyctiphanes norvegica, with respect to reproduction. Comp. Biochem. Physiol., 129A: 373-390.

Antezana, T. - 1999. Hydrographic feature of Magellan and Fuegian inland passages and adjacent Subantarctic waters. Sci. Mar., 63(Suppl. 1): 1-16.

Arntz, W.E. and T. Brey. - 2003. Expedition ANTARKTIS XIX/5 (LAMPOS) of RV "Polarstern" in 2002. Rep. Polar Mar. Res. 462: 1-122.

Arntz, W.E., M. Gorny, R. Soto, M.A. Lardies, M.A. Retamal and I.S. Wehrtmann. - 1999. Species composition and distribution of decapod crustaceans in the waters off Patagonia and Tierra del Fuego, South America. Sci. Mar., 63(Suppl. 1): 303-314.

Bacardit, R. - 1986. Larvas de Crustacea Decapoda del Mar Patagónico Argentino, incluyendo el talud continental, adyacencias a la Tierra del Fuego e Islas Malvinas. Aspectos morfológicos, ecológicos y filogenéticos. Doctoral thesis, Univ. Buenos Aires, Argentina.

Bergstrom, B.I. - 1991. Reproductive cycle and the effect of temperature on oogenesis of Pandalus borealis Kroyer, 1838. J. Shellfish Res., 10: 327-331.

Boschi, E.E., C.E. Fischbach and M.I. Iorio. - 1992. Catálogo ilustrado de los crustáceos estomatópodos y decápodos marinos de Argentina. Frente Marítimo, 10A: 7-94.

Brante, A., M. Fernández, L. Eckerle and F. Mark. - 2003. Reproductive investment in the crab Cancer setosus along a latitudinal cline: egg production, embryo losses and embryo ventilation. Mar. Ecol. Prog. Ser., 251: 221-232.

Calcagno, J.A., G.A. Lovrich, S. Thatje, U. Nettelmann and K. Anger. - 2005. Growth of young-of-the-year lithodids, Lithodes santolla and Paralomis granulosa, reared at different temperatures. J. Sea Res., 54: 221-230.

Chapelle, S. - 1977. Lipid composition of tissues of marine crustaceans. Biochem. Syst. Ecol., 5: 241-249.

Clarke, A. -1979 . On living in cold water: K-strategies in Antarctic benthos. Mar. Biol., 55: 111-119.

Clarke, A. - 1983. Life in cold waters: the physiological ecology of polar marine ectotherms. Oceanogr. Mar. Biol. Annu. Rev., 21: 341-453.

Clarke, A. - 1987. Temperature, latitude and reproductive effort. Mar. Ecol. Prog. Ser., 38: 89-99.

Crame, A. - 1999. An evolutionary perspective on marine faunal connections between southernmost South America and Antarctica. Sci. Mar., 63(Suppl. 1): 1-14.

Fernández, M., C. Bock and H.O. Pörtner. -2000 . The cost of being a caring mother: the ignored factor in the reproduction of marine invertebrates. Ecol. Lett., 3: 487 - 494.

Frederich, M., F.J. Santoris and H.O. Pörtner. - 2001. Distribution patterns of decapod crustaceans in polar areas: a result of magnesium regulation? Polar Biol., 24: 719-723.

Gorny, M. - 1999. On the biogeography and ecology of the Southern Ocean decapod fauna. Sci Mar., 63(Suppl. 1): 367-382.

Gorny, M. and M.R. George. - 1997. Oocyte development and gonad production of Nematocarcinus lanceopes (Decapoda: Caridea) in the eastern Weddell Sea, Antartica. Polar Biol., 17: 191-198.

Grabbert, S., S. Gerdes, R. Knust and H. Bohlmann. - 2003. Hydrography. In: W.E. Arntz and T. Brey (eds.). The expedition ANTARKTIS XIX/5 (LAMPOS) of RV "Polarstern" in 2002. Rep. Polar Mar. Res., 462: 89-93.

Graeve, M. and I.S. Wehrtmann. - 2003. Lipid and fatty acid composition of Antarctic shrimp eggs (Decapoda: Caridea). Polar Biol., 26: 55-61.

Gutt, J., E. Helsen, W.E. Arntz and A. Buschmann. - 1999. Biodiversity and community structure of the mega-epibenthos in the Magellan region (South America). Sci. Mar., 63(Suppl. 1): 155-170.

Haefner, P.A. and D.H. Spaargaren. - 1993. Interactions of ovary and hepatopancreas during the reproductive cycle of Crangon crangon (L.) I. Weight and volume relationships. J. Crustacean Biol., 13: 523-531.

Harrison, K.E. - 1990. The role of nutrition in maturation, reproduction and embryonic development of decapod crustaceans: a review. J. Shellfish Res., 9: 1-28. 
Havenhand, J. and C. Todd. - 1989. Reproductive effort of the nudibranch molluscs Adalaria proxima (Alder and Hancock) and Onchidoris muricata (Muller): an evaluation of techniques. Funct. Ecol., 3: 153-163.

Hedgpeth, J.W. - 1969. Introduction to Antarctic zoogeography. Am. Geogr. Soc., Antarct. Map Folio Ser., 11: 1-41.

Hines, A.H. - 1982. Allometric constraints and variables of reproductive effort in brachyuran crabs. Mar. Biol., 69: 309-320.

Hughes, R.N. and D.J. Roberts. - 1980. Reproductive effort of winkles (Littorina spp.) with contrasting methods of reproduction. Oecologia, 47: 130-136.

Makarov, R.P. - 1970. Biology of the Antartic shrimp Notocrangon antarticus (Decapoda, Crangonidae). Zool. Zh., 59: 28-37.

Matthews, L.H. - 1932. Lobster-krill. Anomuran Crustacea that are the food of whales. Discovery Rep., 5: 467-484.

Mourente, G. and A. Rodríguez. - 1991. Variation in the lipid content of wild-caught females of the marine shrimp Penaeus kerathurus during sexual maturation. Mar. Biol., 110: 21-28.

Parr Instrument Company. - 1993. 1672 Thermometer. Operating instruction manual. Parr, Moline.

Pearse, J. and J. Mc Clintock. - 1991. Reproduction of Antarctic benthic marine invertebrates: tempos, modes, and timing. Amer. Zool., 31: 65-80.

Pérez-Barros, P., F. Tapella, M.C. Romero, J.A. Calcagno and G.A. Lovrich. - 2004. Benthic decapod crustaceans associated to captures of Munida spp. (Decapoda: Anomura) in the Beagle Channel, Argentina. Sci. Mar., 68: 237-246.

Rayner, G.W. - 1935. The Falkland species of the crustacean genus Munida. Discovery Rep., 10: 212-245.

Retamal, M.A. - 1981. Catálogo ilustrado de los crustáceos decápodos de Chile. Gayana, 44: 1-110.

Retamal, M.A. - 2000. Decápodos de Chile. World Biodiveristy Database. CD-ROM Series. ETI-UNESCO.

Romero, M.C. - 2003. Hábitos alimentarios y bioenergética de la langostilla Munida subrugosa (Decapoda: Anomura) del Canal Beagle, Argentina. Doctoral Thesis, Univ. Nac. Córdoba, Argentina.
Sokal, R.R. and F.J. Rohlf. - 1995. Biometry, the principles and practice of statistics in biological research. W.H. Freeman and Company. New York.

Styrishave, B. and O. Andersen. - 2000. Seasonal variations in hepatopancreas fatty acid profiles of two colour forms of shore crabs, Carcinus maenas. Mar. Biol., 137: 415-422.

Tapella, F. - 2002. Reproducción, crecimiento, distribución y abundancia de la langostilla Munida subrugosa (Anomura, Galatheidae) del Canal Beagle, Tierra del Fuego, Argentina. Doctoral thesis. Univ. Nac. Córdoba, Argentina.

Tapella, F., G.A. Lovrich, M.C. Romero and S. Thatje. - 2002. Reproductive biology of the crab Munida subrugosa (Decapoda: Anomura: Galatheidae) in the Beagle Channel, Argentina. J. Mar. Biol. Ass. U.K., 82: 589-595.

Thatje, S. and W.E. Arntz. - 2004. Antarctic reptant decapods: more than a myth? Polar Biol., 27: 195-201.

Thatje, S., S. Schnack-Schiel and W.E. Arntz. - 2003. Developmental trade-offs in Subantarctic meroplankton communities and the enigma of low decapod diversity in high southern latitudes. Mar. Ecol. Prog. Ser., 260: 195-207.

Thatje, S., G.A. Lovrich, G. Torres, W. Hagen and K. Anger. 2004. Changes in biomass, lipid, fatty acid and elemental composition during the abbreviated larval development of the subantarctic shrimp Campylonotus vagans. J. Exp. Mar. Biol. Ecol., 301: 159-174.

Thatje, S., K. Anger, J.A. Calcagno, G.A. Lovrich, H.O. Pörtner and W.E. Arntz. - 2005. Challenging the cold: crabs reconquer the Antarctic. Ecology, 86: 619-625.

Wehrtmann, I. and G. Kattner. - 1998. Changes in volume, biomass, and fatty acids of developing eggs in Nauticaris magellanica (Decapoda: Caridea): a latitudinal comparison. J. Crustacean Biol., 18: 413-422.

Wen, X., L. Chen, C. Ai, Z. Zhou and H. Jiang. - 2001. Variation in lipid composition of Chinese mitten-handed crab, Eriocheir sinensis during ovarian maturation. Comp. Biochem. Physiol., 130B: 95-104. 
